\title{
Proposal of management skills and academic preparation for directors in public universities
}

\section{Propuesta de habilidades directivas y preparación académica para directivos en universidades públicas}

DE LA GARZA-CIENFUEGOS, Sandra*†, ARMENDARIZ-MARTINEZ, Juan Francisco, CARMONA-MARTINEZ, Reynaldo and BARRIENTOS-MENDEZ, Karina

Universidad Autónoma de Coahuila, Facultad de Contaduría y Administración

ID $1^{\text {st }}$ Author: Sandra Patricia, De La Garza-Cienfuegos / ORC ID: 0000-0002-7018-1252, CVU CONACYT ID: 320839

ID $1^{\text {st }}$ Coauthor: Juan Francisco, Armendariz-Martinez / ORC ID: 0000-0003-2863-6759, CVU CONACYT ID: 533088

ID $2^{\text {nd }}$ Coauthor: Reynaldo, Carmona-Martínez / ORC ID: 0000-0002- 6960-0299, CVU CONACYT ID: 549393

ID $3^{\text {rd }}$ Coauthor: Karina, Barrientos-Méndez

DOI: $10.35429 /$ JSETM.2019.5.3.9.16

Received July 29, 2019; Accepted December 28, 2019

\begin{abstract}
He main objective is to make an excellent selection of participants to director in public universities, identify the profile of higher education and base it on competencies before participating in an autonomous election, with the purpose of detecting its effectiveness and efficiency, verify if it has knowledge of the institution, strengths and opportunities, Knowledge of the Educational Model, academic preparation, Administrative Preparation, Skills, Creativity, Decision-making, Leadership, Honesty, Ethics and personal development. Detecting problems that affect students and teachers is significant in order to find the solution to these problems and also to improve the competitiveness and quality of public universities. Exploratory and descriptive research was carried out based on a mixed, qualitative research scheme with documented foundations of the type, Descriptive and Quantitative elaboration of an Instrument applying a sample of 92 surveys, with a confidence level of $95 \%$ and a margin of error $5 \%$, interviews, real variables, statistical management, hypothesis testing, contributing to the development of new strategies and methods applied in other countries.
\end{abstract}

Competitiveness, Selection and Management Skills

\begin{abstract}
Resumen
El Objetivo principal es realizar una excelente selección de los participantes a director en universidades públicas, identificar el perfil del líder de Instituciones de educación superior en México y basarlo en competencias antes de participar en una elección autónoma, con el propósito de detectar su eficacia y eficiencia, verificar si cuenta con conocimiento de la institución, fortalezas y oportunidades, Conocimiento de Modelo Educativo, preparación académica, Preparación Administrativa, Habilidades, Creatividad, Toma de decisiones, Liderazgo, Honestidad, Ética y desarrollo personal. Detectar problemas que afectan a los estudiantes y docentes es significativo para así encontrar la solución a dichos problemas y también para mejorar la competitividad y calidad de las universidades públicas. Se realizó investigación exploratoria y descriptiva apoyada en un esquema de investigación mixta, cualitativa con fundamentos documentados de tipo, Descriptivo y Cuantitativo elaboración de un Instrumento aplicando una muestra de 92 encuestas, con un nivel de confianza del $95 \%$ y un margen de error 5\%, entrevistas, variables reales, manejo estadístico, comprobación de Hipótesis, contribuyendo en el desarrollo de nuevas estrategias y métodos aplicados en otros países.
\end{abstract}

Competitividad, Selección y Habilidades Directivas

Citation: DE LA GARZA-CIENFUEGOS, Sandra, ARMENDARIZ-MARTINEZ, Juan Francisco, CARMONAMARTINEZ, Reynaldo and BARRIENTOS-MENDEZ, Karina. Proposal of management skills and academic preparation for directors in public universities. Journal Schools of economic Thought and Methology. 2019. 3-5: 9-16.

\footnotetext{
* Correspondence to Author (email: cienfuegoss2005@yahoo.com.mx)

$\dagger$ Researcher contributing as first author.
} 


\section{Introduction}

(Haro, 2002: 113). The debate on party nomination mechanisms in Latin America gained a lot of strength and open interns were advocated from many sectors as the purest democratic procedure if given by the will of all voters in the matter of selecting authorities. Since then it was suggested that as the elected candidate must have an institutional work aimed at achieving the general interest, the legitimacy of origin of that candidacy would have a much pure source. (Zovatto, 2001: 16). The selection procedures imply the submission of the decisions of a minority, while those who are selected through open interns will be due to the unappealable will of a majority, with which this mechanism provides additional legitimacy to the political process of democratic origin. a study of (Gallo, 2005) p. 277-289.

The competitiveness among teachers to reach a position of director in public universities is not precisely personal and when choosing it is difficult to select the best candidate for the sake of teachers and students, the vast majority there are groups allied to each of the participants with different personal purposes, for this reason this study is focused on analyzing how the dean and the role he represents are selected in other universities. In 2005, Zuluaga made it clear that "The qualities that must meet: The University Dean will therefore have to be the driver with the skills, abilities and competencies for this leadership. Its regulatory functions rest in the statutes; However, this investiture entails some demands that deserve to be highlighted. Assuming the proposed leadership means: 1) first of all, to have the conviction of the responsibility to train professionals with knowledge; 2) be the protagonist of the training process for new professionals, so that with teachers and students they face and solve the problems, sharing and executing the commitments; 3 ) be provocative, motivating and guiding the educational task of teachers, for the achievement of an active, participatory and flexible pedagogy, student-centered and based on the construction of knowledge and learning, through the strengthening of comprehensive training and the development of creative imagination and recursion; its needs and possibilities, for a permanent renewal of the learning process and for the promotion and development of research and extension.
The Dean of a faculty or institution that has the mission of training professionals, must finally satisfy the stated merits, but in addition to his status as leader, be an exemplary citizen with professional and ethical solvency, an admired and respected figure and a dreamer bold. "That ensures the academic quality of their dependence as the finished product (professional quality of the students when they leave.). In 2016, Rodríguez, Culquichicón and Gil made it clear that one of the objectives of educational institutions is to promote scientific research.1 This responsibility falls directly on their directives and teachers. The researcher encourages creativity and critical thinking of his students, thereby learning is vitalized. That is why the question has arisen as to whether those who are in charge of higher education institutions, particularly the deans, should have or have had scientific and research participation active enough to be aware of their importance, as well as to encourage and have policies in this regard in undergraduate, which ultimately becomes the pillar to assess the quality and impact of higher education in its graduates.

\section{Justification}

The directors, academics and students constitute the backbone of the university, especially the directors who are responsible for making the institution's relations and proper functioning as enriching, harmonious and efficient as possible.

\section{Problem}

The lack of experience and training of the successor to give continuity to the honor of continuing to raise the academic quality as director of the institution in the wonderful relay career, leaving very high the name of his faculty. To turn the page once the election is over, it is sometimes difficult, not just for the principal, but for teachers or students, as they do not support the strengthening initiatives of the university community. So determining what are the most important factors to consider in management skills and decision making is interesting in this research.

\section{Hypothesis}

H1: The studies, values and managerial skills of a university director influence raising the impact quality of higher education of its graduates 
H0: The studies, values and managerial skills of a university director do not influence in raising the quality of impact of the higher education of its graduates

\section{General objective}

To analyze the factors and strategies of managerial skills and academic preparation that a candidate must have to occupy a position of director of faculties of higher education.

\section{Specific objectives}

- Analyze factors that influence a good selection of the candidate for Director of faculties.

- Establish the management skills strategies that should be given by those who run a higher education faculty.

- Define the basic factors and strengths of a leader for your institution.

\section{Research questions}

- What are the factors that influence a good selection of candidate for director of a public university faculty?

- Are there managerial skills strategies that should be directed by those who run a higher education faculty?

- Are there basic factors and strengths of a leader for your institution?

\section{Theoretical framework}

The importance of the educational model and its effectiveness as a basis in academic quality, improvement of the society and economy of the country. A constant concern of the 60s and 70s since the first European reforms according to Alvares 2003. The current educational period that was born in the $90 \mathrm{~s}$ is characterized by a rapid adaptation to continuous changes and the high pace of technological evolution, forcing the teacher to adapt to new situations, therefore, the director becomes a better prepared agent, continually facing academic and conflicting challenges.
In 2013 Collado made clear some European systems of the role and competences of directors, for example in France, Italy and Belgium, the director fulfills two tasks, one administrative-economic and the other institutional representation and maintenance of the discipline although he must supervise programming does not have power over pedagogical decisions being one of the least evolved models in Europe, under social prestige and low demand. England and Wales in these countries the directors enjoy great social prestige that makes them participate in decision-making and high pay, here the director is selected by the local authority that should assess their experience, training and management project encompassing thus total autonomy to organize the center and teachers are evaluated every 4 years measuring the success of their proposals. In Austria, Hungary, Germany and the Netherlands, the managerial function forms of great social prestige, being occupied by officials who access the position of director by public contest, in this contest their teaching experience is valued as well as their training in administration and school training, Its main function is to coordinate teaching and pedagogically control the discipline, supervise teachers and administer the center. However, in the Scandinavian countries the education system is booming due to its excellent results especially those of Finland where the role of the director is also very studied, there the directors are selected by a local commission, enjoying great autonomy and authority, Every 4 or 5 years they have an audit to see if they have fulfilled the objectives set and have performed their function.

UNAM founded in 1910, Tec de Monterrey that illustrates young people since 1943, are in all rankings in first and second place. One of the university that also remains within the first 10 places is the Autonomous University of Nuevo León (UANL), in the two autonomous universities it is worth noting how they select the director of a faculty by their statute and in addition to a number of requirements, where the directors of Faculties and Schools are appointed by the Governing Board, from three lists formed by the Rector, who previously submits them to the approval of the respective Technical Councils. 
According to Hay Group (2000), all human resources processes start from a competency profile, which should reflect the behavior that is needed for the future success of the organization. The competences are associated with a general area, that is, a The characteristics that an individual must meet according to the tasks to be performed in the organization and by which the future of the same will be determined, the generic ones are those associated with the personality (achievement, influence, personal effectiveness, problem solving, management of people) and the techniques are those associated with the knowledge of a certain area. In fact, the main qualities of a Leader James Hunter does not offer the following list of who is fit to exercise leadership: he is honest, trustworthy, exemplary, aware of others, committed, demands responsibility from his employees, encourages people, has a positive and enthusiastic attitude, appreciates people and treats them with respect, finally the audacity in the decision, the constancy and strength in command are basic factors of the humble attitude of the boss (Llano 2008) .pag. 15-17, 388.

\section{Leadership Theory}

According to Lussier and Achua (2011), the theory, trait and behavior of a leader, were attempts to find the best leadership style in all situations, theories enjoy a practical value because they are used to better understand, predict and Control successful leadership. A leadership model is an example for emulation or use in a specific situation.

Leadership theory is the largest topic that explains the variables and leadership styles that will be used in a contingency situation. In the theory of contingencies and model variables, it tells us that leaders exhibit a range of behaviors of various moldable situations from which leaders and followers interact, determining the demands and constraints that confront the leader.

The global leadership is so important that it mentions that from one place to another with different cultures and different lifestyles, leaders with an international and flexible openness are needed for any place.
In 2008, Llano made it clear that humility in the person of a director was accompanied by a deep firmness in his decisions, those soft or meek people, shy without bragging, who shunned the attention, reserved and polite, of gentle manners that They did not talk about themselves, convinced that there are many people in this organization who would do the job better than me, inherently humble who first serve people with an intense professional will. This implies treating our subordinates as if they ever became our bosses, surely they will be if we are capable of such leadership. It is necessary to be firm but humble. Those who do not have a vocation for service will not respond to the needs of others when they negatively affect their own lives. The right decision or the magnanimous decision requires another virtue "boldness" referring to personal abilities. If magnanimity refers to what I must achieve, boldness refers to the resources that I have to get to achieve it.

The main qualities and forces for the act of directing are: a) Objectivity about the circumstances, b) humility, c) Magnanimity about the goals, d) Audacity in the decision, e) Trust in the people, f) Strength in the face of difficulties, g) Confidence in command.

Winning means surpassing yourself, you have every right to win, to succeed, to become the best. (Viscott 2015). According to Huerta and Rodríguez (2014) Management is the process that a person performs to influence others and, thus, get a group to work together effectively. Management has to do with aspects such as morals, motivation, leadership, behavior and interpersonal relationships. The fundamental objective is to instill in others the desire to act. The importance of being a tangible part of the administrative process, management must show its relevance at all times, since the image, development and growth of the organization depends on the actions of the directors, justifying their function through the results, thus helping to achieve the goals of the organization.

The power to send includes three functions: a) Determine what must be done (managerial function), b) Establish how it should be done, c) Monitor that what must be done is fulfilled. 
The exercise of managerial skills and leadership is present in all activities that are carried out daily.

The requirement to play various roles. Ramsden (2007: 4-5) sums them up like this:

He is expected to be an excellent teacher, to design courses and apply appropriate teaching methods to meet the requirements of a heterogeneous student population, who knows how to deal with large groups of students, who properly use the new information and communication technologies, that inspires students with zero tolerances to frustration. At the same time, it is expected that it will be highly productive in the investigation, that it can obtain new financial resources, that it juggles to overcome the new administrative demands and be held accountable.

\section{Research Methodology}

The methodology is based on the investigation and descriptive and explanatory supported by a mixed research scheme, qualitative with documented foundations of descriptive and quantitative type using interviews, a field study with real variables, objective developments and relevant statistical management an instrument was applied to 92 teachers from different autonomous universities in the country. With a confidence level of $95 \%$ and a $5 \%$ margin of error, the reliability of the instrument is 0.8 according to the Cronbach's alpha formula.

Sample's size calculation

$$
\mathrm{n}=\frac{\mathrm{N} \mathrm{Z}^{2} p(1-\mathrm{p})}{(\mathrm{N}-1) \mathrm{e}^{2}+\mathrm{Z}^{2} \mathrm{p}(1-\mathrm{p})}
$$

Where:

z 95\% attentive confidence interval,

p True proportion $20 \%$

e Acceptable error margin $8 \%$

N Population size 2,400

\section{Results}

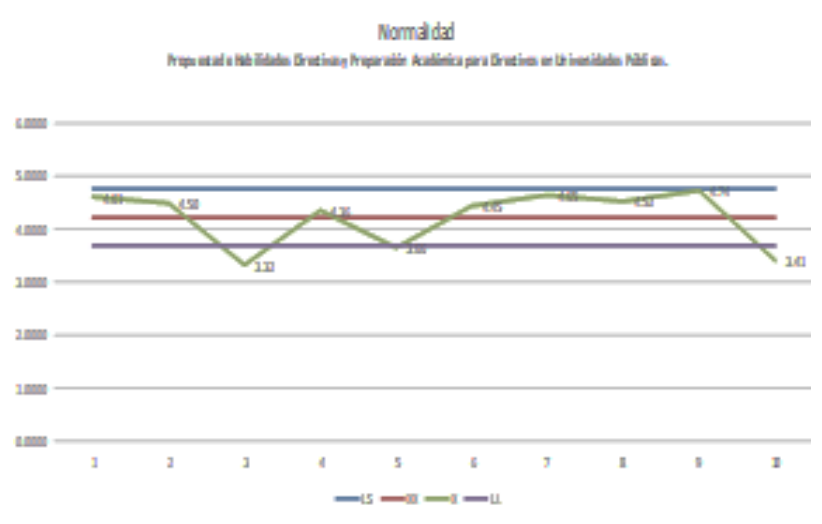

Graphic 1 Normality Analysis of obtained values

\section{Reading Interpretation}

The Variable "The director must train the successor to continue increasing the academic quality (9). It is above the Upper Limit of Normality, which indicates that it is a representative Variable of the Study Phenomenon, which strengthens the hypothesis. The Variables During your career you have been affected in some situation because it is not of the group once the election is over? (3), Is it below the Lower Limit of Normality, which indicates that it is a Variable little representative (Irrelevant) for the study phenomenon The rest of the variables $(1,2,4,5,6,7,8,10)$ are within normality at $\pm 1 \delta$.
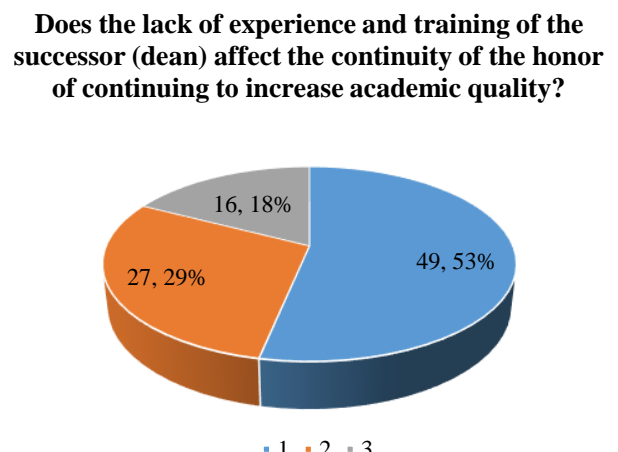

Graphic 2 The variable (4) that is above the average of normality

Within this problem, the fact of the study stands out, where $49.53 \%$ of the respondents consider that the lack of experience and training of the director affects the continuity of the honor of continuing to increase academic quality, $27.29 \%$ consider that 76.82 almost always $\%$ is significant, therefore, the Hypothesis is accepted. 


\begin{abstract}
Ideally, select candidates with characteristics of excellence before participating in an election?
\end{abstract}

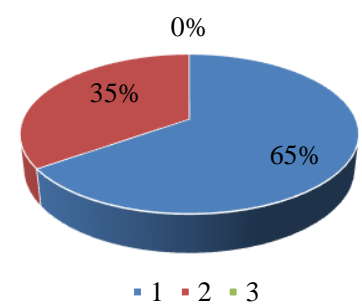

Graphic 3 The variable (7) that is within the normal limit and relatively close to the upper limit

$65 \%$ of respondents believe that it would always be ideal to select candidates with characteristics of excellence before participating in an election. Therefore, the correlational relationship of these 2 significant variables in the study phenomenon is analyzed to verify the effects that contribute to the results. Based on the normality study, we analyze the two most significant variables with cross tables.

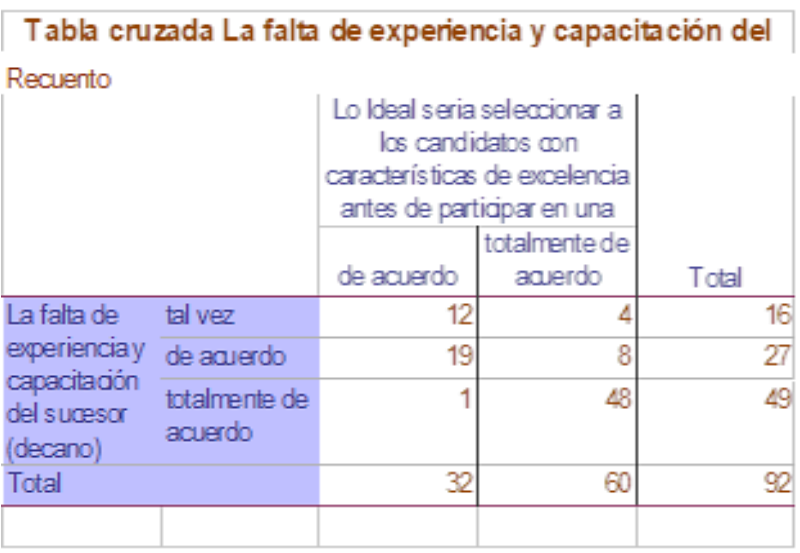

Figure 1 The relationship of dependence between variable 4 and variable $7,53 \%$ of respondents fully agree that the lack of experience and training of a director affects the continuity of the honor of continuing to increase academic quality and ideal it would be to select candidates with characteristics of excellence before participating in an election

Source: own elaboration

\begin{tabular}{|c|c|c|c|c|}
\hline \multicolumn{5}{|c|}{ Medidas simétricas } \\
\hline & & Valor & $\begin{array}{l}\text { Significación } \\
\text { aproximrada }\end{array}$ & $\begin{array}{c}\text { Significadón } \\
\text { exacta }\end{array}$ \\
\hline $\begin{array}{l}\text { Nominal por } \\
\text { Nominal }\end{array}$ & $\begin{array}{l}\text { Coeficiente } \\
\text { de } \\
\text { contingencia }\end{array}$ & 0.592 & 0.000 & 0.000 \\
\hline N de casos V & lidos & 92 & & \\
\hline
\end{tabular}

Figure 2 Regarding the contingency tables the dependence between the two variables is high
According to Arce (2017) regarding cross tables or contingency tables, state the strength of the relationship as follows:

0 to 0.25 There is little dependence

\subsection{5 to 0.5 Dependence is average}

\subsection{1 to 0.75 Dependence is High}

$>0.76$ There is a very high dependence.

In an interview with former directors of public universities, they mentioned that the first year of their management is lost by not having a training by the outgoing director and leaving specific projects, as well as sharing and transmitting their empirical knowledge.

\section{Conclusions}

The factors that become increasingly important in the results of the activities and functions of a director, the first of these is his academic preparation and general knowledge of the position, becoming a better prepared agent, continually facing academic challenges. Second strategic ability to lead the successful rubble of the institution. Third creativity, the implementation is perhaps the most difficult responsibility that a manager has, because it is here that they not only need skills but competencies to reach the goal.

The fourth strength is the ability to communicate, especially that the strategies are clear to all those who are part of the institution, if it is not achieved it is feasible to fall into inaccuracies causing unnecessary conflicts, a good communicator is the one who knows how to listen and goes Hand in hand with teamwork and conflict resolution, make the conflict something positive and successful for the institution. The fifth and main strength is honesty and prudence, it is the ability to act at the right time and shut up when you have to do it, justice to give everyone what they deserve, recognize their work, stand firm against any adversity resulting to Be a trustworthy person. 
It is worth mentioning that In fact the main qualities of a Leader James Hunter does not offer the following list of who is fit to exercise leadership: he is honest, trustworthy, exemplary, aware of others, committed, demands responsibility from his employees, encourages people, have a positive and enthusiastic attitude, appreciate people and treat them with respect, finally the boldness in the decision, the constancy and strength in command are basic factors of the humble attitude, the actions of the directors depends on image, development and growth of the organization, justifying its function through the results, thus helping to achieve the goals of the institution. According to Huerta, Rodríguez (2014).

The management skills strategies that should be taken by those who run a higher education faculty are: it has to do with aspects such as morals, motivation, leadership, behavior and interpersonal relationships.

The main objective is to instill in others the desire to act, the direction is the process that a person carries out to influence others so that they work more effectively individually or in groups, quality is reflected in the achievement of the objectives and in the control efficiency The strategies are summarized in 1. Knowing how to treat staff (Human Relations), 2. Receive and channel complaints from their collaborators (Conflict Management), 3. Conduct meetings, even if they are small (Communication), 4. Stimulate at all times communication, 5 . Maintain discipline and fulfillment of work. (Control) 6.- Nonverbal communication, 7.Know how to speak in public and hold a conversation (Oral and Written Expression), 8.Know how to know and control one's own and others' emotions. (Emotional Intelligence), 9 the scarcity of resources and solve problems in the original way to reach new solutions (Creativity), 10. Have a good degree of self-control and selfcriticism, which guarantees at all times the predominance of reason over passion. (Negotiation).
The basic factors and strengths of a good leader for the institution are reflected in the quality and improvement day by day and especially at the end of its management and evaluation. Various types of decisions are made, moving forward or stopping when there are obstacles, not allowing them to paralyze your actions, having security and deciding correctly are one of the main qualities of the leader, it is necessary to experience risk and learn from triumphs and failures. In fact, the main qualities of a Leader James Hunter does not offer the following list of who is fit to exercise leadership: he is honest, trustworthy, exemplary, aware of others, committed, demands responsibility from his employees, encourages people, has a positive and enthusiastic attitude, appreciates people and treats them with respect, finally the boldness in the decision, the constancy and strength in command are basic factors of the humble attitude of the boss.( Llano 2008)

In an interview with former directors of different autonomous universities, they mentioned that it is relevant to take into account studies, experience and professional ethics, analyzing work performance over the years, taking into account their trajectory of scientific research. From personal experience, good training is necessary before beginning its management to strengthen time management when there is no experience in running an institution. This allows us to verify the effects indicated in the results of the methodological study, where H1 is accepted. The studies, values and managerial skills of a university director influence in raising the quality of impact of the higher education of its graduates. Therefore, it is proposed to analyze the candidates who wish to occupy a management position in an institution of higher education and come to office, Therefore, it seems appropriate to train them in the weak points, after an analysis or interview. Based on the methodological study, it is convenient to make it clear that as well as receiving training from the outgoing director, he undertakes to do the same once his management is finished. All with the same purpose, increase the academic quality of graduates, teachers, administrative staff and the same institution. 


\section{References}

Álvarez, Manuel (2003) "La dirección escolar en el contexto europeo" Revista Organización y gestión educativa, pag. 15-19.

Collado,Issac (2013). "El director escolar, competencias, funciones y característcas, Propuestas de mejora del centro"

De Arce, Rafael (2017) Tablas de Contingencia o Tablas Cruzadas, http:/www.uam.es/personal_pdi/económicas/rar ce//pdf/demo_corrup_cross_tab.mx

Gallo, A. (2005). Mecanismos de selección partidaria y legitimidad de las candidturas. El debate en latino-américa. RIPS. Revista de Investigaciones Políticas y Sociológicas, 4 (2), 277-289.

HAY GROUP. (2000). Las Competencias: clave para una Gestión Integrada de los recursos humanos. España, Ediciones Deusto, S.A., pp. 191 .

Haro, Ricardo (2002): "Elecciones primarias abiertas. Aportes para una mayor democratización del sistema político." En Constitución, poder y control. Universidad autónoma de México.

Huerta Juan (2014) Desarrollo de habilidades Directivas, ed. Pearson, pág. 1-419. Ed. México.

Llano Carlos (2008). Humildad y Liderazgo. 7ed. Editorial Ruz, México. Pàg, 1-391.

LussierRobertN.,AchuaChristopherF.(2011).Li derazgo.4ta.Ed.México.Cengage,Pearson.

Learning

Ramsden, Paul (2007), Learning to Teach in Higher Education, Londres/Nueva York, Routledge Falmer.

Zovatto, Daniel (2001): "La reforma políticoelectoral en América Latina: evolución, situación actual y tendencias; 1978-2000" Revista CLAD, Reforma y democracia $\mathrm{N}^{\circ} 21$ octubre de 2001, Centro Latinoamericano de Administración para el Desarrollo, CLAD, Caracas, pp 15-22
Zuluaga T., Fabio Nelson, Calidades para un Decano. Revista colombiana de Ciencias Pecuarias [en línea] 2005, 18 (Enero-Abril) : [Fecha de consulta: 7 de agosto de 2019] Disponible en : ISSN 0120-0690 